\title{
e-interview
}

\section{Peter Hoare}

Peter Hoare was until recently Senior Lecturer at the University of Edinburgh and Consultant Psychiatrist at the Royal Hospital for Sick Children, Edinburgh, where he had worked for the past 28 years. He read Psychology, Philosophy and Physiology at the University of Oxford before completing undergraduate and postgraduate medical training there. He has a longstanding research interest in neuropsychiatry, publishing extensively on the psychiatric aspects of childhood epilepsy. More recently, he has been involved in the clinical trials of the newer pharmacological medications for attention-deficit hyperactivity disorder.

\section{If you were not a psychiatrist} what would you do?

A difficult one. I originally wanted to become an academic psychologist, but felt that the world of maze learning by rats was too remote from the real life. On a fantasy level, I'd liked to have been an architect, designing something permanent and beautiful, a Frank Gehry manqué.

What has been the greatest impact of your profession on you personally? Seeing patients. I was, and am, still amazed at the willingness of children and their parents to reveal the intimate details about their personal lives in such a trusting manner. It's a privilege to hear their life stories and something we must treat with the utmost respect. A major clinical dilemma working with the parents of disturbed children is to avoid being judgemental about their behaviour, while at the same time enabling them to see their child's behaviour from a different perspective.

\section{What are your interests outside} of work?

My three loves are supporting Liverpoo Football Club, reading biographies and going to the opera. I have been fortunate enough to visit many opera houses throughout the world, but my most amazing experience was going to the Wagner Opera Festival at Bayreuth in 2007. How Wagner could write such sublime music, yet behave in such a dysfunctional manner in everyday life? A psychiatric conundrum!

Who was your most influential trainer, and why?

Working for Professor David Taylor as a registrar at the Park Hospital in Oxford. Supervision consisted of endless unresolved disputes about the brainlessness or mindlessness of psychiatry, long before Leon Eisenberg coined the phrase.

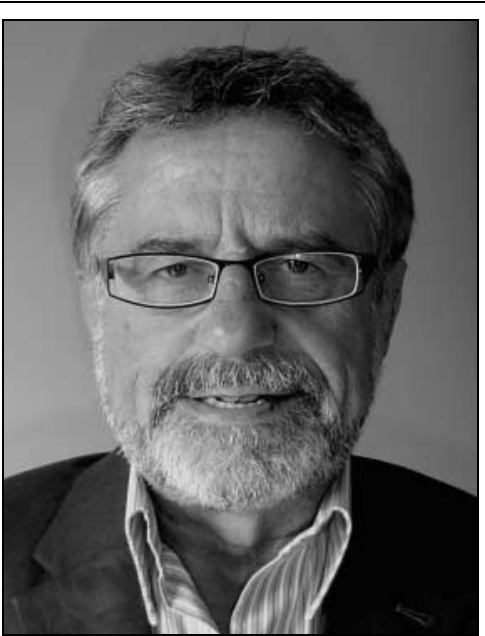

An exchange of a small cigar usually terminated the session.

What job gave you the most useful training experience?

As a research fellow in the Oxford University Department of Psychiatry with Michael Gelder. He gave me complete freedom to explore all avenues, but at a price I had to produce a research degree. I always remember his sage advice about thesis writing: it's like a filter funnel, start wide and then narrow down.

\section{Which publication has influenced} you most?

Professionally, Michael Rutter's Isle ofWight study. It showed me that research in child psychiatry was possible and that it could be scientific. Personally, undoubtedly Marcel Proust's A La Recherche duTemps Perdu. In the 1980s, I had the good or ill fortune to teach child psychiatry on a post-graduate paediatric course in Riyadh, Saudi Arabia, each year. Other than teaching, there was little else to do except read and admire the sand. So each year I would take a couple of volumes and read them from cover to cover. The psychological and social insights in Proust's writing are phenomenal, enriching my own understanding of people profoundly.

How has the political environment influenced your work?

Despite their protestations, politicians continue to undervalue the importance of childhood for the well-being of society. They do not accept William Wordsworth's aphorism that 'the child is father to the man', so that one has had a perennial struggle to keep children's psychological needs on the political agenda.

What part of your work gives you the most satisfaction?

Helping children and families on the rocky road that's life.
What do you least enjoy?

olumns

The innumerable meetings that have no executive authority. The paralysis in decision-making has a long-term demoralising impact on all health professionals it's not so much that there are too many chiefs, but rather there's no chief at all!

What is the most important advice you could offer to a new trainee? Work hard, study hard and enjoy yourself. Find a speciality that stimulates your intellectual curiosity as well as one that suits your personality and outlook on life. See as many patients as you can - the more you see, the more you learn.

Do you think psychiatry is brainless or mindless?

A non-question. Psychiatry has the virtue and the vice of combining the physical and the psychological. I strongly believe that there's no such entity as a schizophrenic but rather there's a person with schizophrenia. We must see the person in the disorder, not just the disorder itself.

\section{What single area of psychiatric practice is most in need of develop- ment?}

I know I would say this, but the importance of child development for the child and for the future adult is still not given the recognition it deserves. How can you understand the adult without understanding the child? I always think it's ironic that on most teaching courses for trainees, child psychiatry almost invariably comes at the end rather than the beginning.

\section{What single area of psychiatric} research should be given priority? The childhood precursors of major adult disorders. In the 1990s, I was involved in an epidemiological survey of all child psychiatry out-patients throughout Scotland. I'd love to find out what has happened to the 18000 participants of the original study.

\section{How would you like to be} remembered?

This is the sort of question that the late Anthony Clare would have asked in his 'In the Psychiatrist's Chair'series. I'm always struck how former colleagues rapidly fade from the memories of the present-tempus fugit! This is inevitable, but rather chastening. I would like to answer the question by saying that I hope that I had fulfilled some maxims in Rudyard Kipling's poem If: 'If you can meet with triumph and disaster and treat those impostors just the same...' etc

\section{Dominic Fannon}

doi: 10.1192/pb.bp.108.022020 